Lin Xiaoping, Children of Marx and Coca-Cola. Chinese Avant-garde art and independent cinema

Honolulu, University of Hawaii Press, 2010, 312 pp.

\title{
Aurelia Dubouloz
}

Translator. N. Jayaram

\section{OpenEdition}

\section{Journals}

\section{Electronic version}

URL: http://journals.openedition.org/chinaperspectives/5592

DOI: 10.4000/chinaperspectives.5592

ISSN: 1996-4617

\section{Publisher}

Centre d'étude français sur la Chine contemporaine

\section{Printed version}

Date of publication: 30 July 2011

Number of pages: 82-83

ISSN: 2070-3449

\section{Electronic reference}

Aurelia Dubouloz, « Lin Xiaoping, Children of Marx and Coca-Cola. Chinese Avant-garde art and independent cinema », China Perspectives [Online], 2011/2 | 2011, Online since 30 June 2011, connection on 24 September 2020. URL : http://journals.openedition.org/chinaperspectives/5592 : DOI : https://doi.org/10.4000/chinaperspectives.5592

\section{This text was automatically generated on 24 September 2020}

(c) All rights reserved 


\section{Lin Xiaoping, Children of Marx and Coca-Cola. Chinese Avant-garde art and independent cinema}

Honolulu, University of Hawaii Press, 2010, 312 pp.

\section{Aurelia Dubouloz}

Translation : N. Jayaram

Xiaoping, currently associate professor at Queens College, New York, says in his introduction that he lived in China before moving to the United States, where he obtained a doctorate in 1993 at Yale. His book, second in the Critical Interventions series published by the University of Hawaii, offers a complementary study of the artistic avant-garde and of independent Chinese cineastes against the background of a post-socialist China in the throes of capitalist globalisation. Lin focuses his study on artists living in Beijing and New York, megalopolises whose transnational aspects are well reflected in their preoccupations, and on works produced between 1998 and 2008, the period representing China's rapid integration with the world. Rejecting both the Chinese official system and the

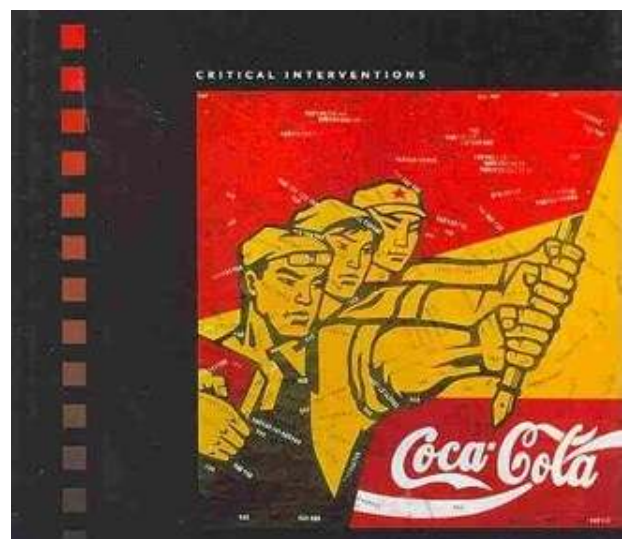

CHILDREN OF MARX AND COCA COLA

CHINESE AVANT-GARDE ART AND INDEPENDENT CINEMA. Western capitalist model while at the same time producing for the market, the artists and cineastes find themselves at the heart of a paradox that is one of the book's subjects. "Post-socialist trauma" (p. 208), 
Chinese nationalism, and denunciation of globalisation thus serve as the basis for analysing a number of installations and films, often augmented by the author's own anecdotes. It is interesting to see the rapprochements developed between art and cinema or between Chinese and Western cultures, especially in the introduction, where Andy Warhol serves to link these different elements.

2 The first part, "Re-creating Urban Space in Avant-garde Art," presents photographs and video installations by Beijing artists operating under the influence of globalisation on public and private space. Clear-cut dichotomies between modernity and tradition, masculine and feminine, capitalist globalisation and Chinese nationalism do not divert from the interesting analyses demonstrating the irony of a new Beijing where the government remains the patron of globally recognised avant-garde architecture. A study of Yin Xiuzhen's installation The Ruined City takes in the capital's urban transformations while offering comparisons with American feminist art. This section ends with an introduction to three New York-resident artists who in Lin's view represent a post-modern and globalised identity - Cai Guoqiang, Zhang Huan, and Xu Bing.

3 The second part, "China's Lost Youth through the Lens of Independent Cinema," examines a theme that in Lin's view is essential for Chinese cinema: youth consumed by social and economic transformations. Using the theses of Slavoj Žižek ${ }^{1}$ to study five remarkable films from the Sixth Generation, he notes that neo-liberal globalisation is the new evil targeted by Chinese filmmakers. Characters in these films have to constantly adapt to the new capitalist order, with the absence of the father figure serving as a metaphor for the ghost of patriarchal socialism at the heart of the analyses. In a chapter on The Orphan of Anyang (Wang Chao, 2001), Lin refers to "the uncanny power of Chinese matriarchy" (p. 119) in describing the strength of feminine personality replacing the caring role renounced by the Party-state. He also offers several interpretations of city walls as metaphors or symbols. Whether as protectors, signs of confinement, or nostalgic reminders, they are among the common motifs used by artists and cineastes. Finally, Lin presents a study of three recent films depicting women in conflict with their fathers, and former workers failing to take in social and economic changes.

4 The third part examines the void left by Mao-era socialism in feature films as well as in artistic videos. The first three feature-length works by Jia Zhangke are thus seen as "a symbolic man's journey across a ruined post-Mao China" (p. 29). Lin then introduces the work of the artist Yang Fudong, whose aesthetic represents "an ultimate escape from a global nightmarish reality" (p. 165). The analysis of two videos from 2003, Liu Lan and Seven Intellectuals in Bamboo Forest Part I, exposes the absurd nature of references to symbols used in different eras depicted by the artist. The last chapter is an analysis of Ning Hao's film Incense (2003), on the tribulations of a Buddhist nun who sheds the robes in order to survive economically. The description of the numerous and often de-contextualised uses of Buddhist vocabulary reveals the film's hidden irony.

5 In his postscript, Lin reviews various artists and cineastes "whose latest works challenge a Western 'master discourse' on politics, religion, and culture" (p. 29). It still relates to the artists' and cineastes' complex relationship with global culture, except that in this case it is about presenting works through which they have found solutions to the paradox presented in the introduction. The book ends with no actual conclusion, 
but with a presentation of installations by female artists Jiang Jie and Qin Yufen, and a citation by Julia Kristeva, leaving the door open to a "mysterious" twenty-first century.

While Children of Marx and Coca-Cola offers highly detailed analyses of a large number of works, viewing them in a global context, excessive importance attached to citation stifles originality. Lin draws interesting parallels between Chinese and Western cultures, but then the anachronism and absence of real commonalities in some comparisons raise doubts over their choice. In fact, comparing Madame Bovary to a postmodern view of the family or Stolen Life (Li Shaohong, 2005) to Way Down East (D.W. Griffith, 1920) might seem rather incongruous.

7 An insufficient definition of notions such as globalisation, post-socialism, and even avant-garde and independence, as well as a readiness to suit works to the needs of theoretical presuppositions, leads to analyses that are at times rather overworked.

8 Although the author's acquaintances constitute valuable references, it is regrettable that he lacks the ironic touch of Geremie Barmé, who is cited many times, faced with the demon of globalised culture.

\section{NOTES}

1. It concerns a psychoanalytical vision of the encounter with a new system, capitalism, seen as a shock, and of post-socialism experienced as trauma, but also of China presented as a country seeking superpowerdom through cutthroat capitalism. See Slavoj Žižek, On Belief, London and New York, Routledge, 2001; Slavoj Žižek, Welcome to the Desert of the Real: Five Essays on September 11 and Related Dates, London and New York, Verso, 2002.

\section{AUTHORS}

\section{AURELIA DUBOULOZ}

Independent researcher specialised in Chinese film studies. 